\title{
PROGRAM RUMAH BELAJAR SOLUSI VIRTUAL LEARNING SISWA SMP PADA MASA PANDEMI COVID-19
}

\author{
Joni Soleman Nalenan, Yanuarius Seran \\ Universitas Timor \\ Joninalenan07@gmail.com
}

\begin{abstract}
The implementation of this community service was based on the gap in the Learning from Home (BdR) program which in principle uses the method of providing material to students and virtual learning to prevent the spread of the Covid-19 pandemic. However, the reality showed that junior high school students in Tublopo were very difficult to learn by applying these two methods. The Rumah Belajar program implemented by the service team was one solution to overcome the gap in the BdR program in Tublopo. Therefore, the purpose of this Rumah Belajar was to have students comprehensively understand the materials given during learning from home system. This Rumah Belajar Program was carried out through several stages, namely, the survey stage, the application for permission, and the service implementation stage. The results of the service illutrated that the Rumah Belajar program was presumably effective to be implemented in the midst of this pandemic since the results of the analysis of students' work provided had increased significantly.
\end{abstract}

Keywords: virtual learning; rumah belajar; enrichment; language

\begin{abstract}
Abstrak
Pelaksanaan kegiatan pengabdian ini didasarkan pada kesenjangan program Belajar dari Rumah (BdR) yang pada prinsipnya menggunakan metode pemberian materi kepada siswa dan virtual learning untuk mencegah penyebaran pandemi Covid-19. Namun, kenyataan menunjukan bahwa siswa SMP di Tublopo sangat sulit untuk belajar dengan menggunakan kedua metode tersebut. Program Rumah Belajar yang diterapkan oleh tim pengabdi merupakan salah satu solusi untuk menanggulangi kesenjangan program BdR SMP di Tublopo. Program rumah Belajar ini bertujuan untuk memberikan pemahaman yang komprehensif terhadap para siswa terkait materi yang diberikan dalam sistem BdR selama masa pandemi Covid-19. Pengabdian Rumah Belajar ini dilaksanakan melalui beberapa tahap yakni, tahap survei, permohonanan izin, dan tahap pelaksanaan pengabdian. Hasil pengabdian menunjukan bahwa program Rumah Belajar cukup efektif untuk diterapkan di tengah pandemi ini karena hasil analisis pekerjaan siswa yang diberikan mengalami peningkatan yang siginifikan.
\end{abstract}

Kata kunci: virtual learning; rumah belajar; pengayaan; bahasa

Submitted: 2021-08-31

Revised: 2021-10-08

Accepted: $2021-10-26$

\section{Pendahuluan}

Pendidikan merupakan sebuah proses dalam pengubahan sikap serta etika maupun tata laku seseorang atau kelompok untuk meningkatkan pola pikir manusia melalui pengajaran dan pelatihan serta perbuatan yang mendidik. Artinya, pendidikan bukan hanya sebagai proses ataupun sistem transfer pengetahuan, akan tetapi sebagai proses pengubahan etika, norma ataupun akhlak dari setiap peserta didik. Dengan kata lain, pendidikan merupakan sarana dalam membantu atau menolong setiap orang agar dapat menjalani hidupnya dengan baik.

Pembelajaran yang ideal selalu diarahkan pada proses interaksi yang melibatkan guru dan peserta didik. Idealitas pembelajaran dapat tercapai apabila dilakukan secara berkesinambungan untuk mengelola potensi peserta didik dalam memperoleh ilmu pengetahuan (Mansyur, 2020:114 115)

Dalam pelaksanaannya, pendidikan berlangsung di sekolah dengan melibatkan tiga komponen utama, yakni pendidik (guru), siswa, dan sumber belajar yang ditunjang dengan kurikulum yang jelas dan dikemas dalam bentuk pembelajaran yang efektif. Namun, saat ini situasi pendidikan hampir di setiap negara diperhadapkan dengan kondisi yang sangat buruk akibat pandemi Covid-19. Berdasarkan data UNESCO tanggal 19 Maret 2020 terdapat 112 negara yang mengimplementasikan sistem home learning. Indonesia merupakan salah satu dari 101 negara 
yang menerapkan sistem belajar dari rumah di wilayah-wilayah tertentu (Arifa, 2020:14). Di Indonesia, para stakeholder pendidikan sedang berusaha untuk menghadirkan solusi dalam menanggulangi pendidikan di setiap satuan pendidikan. Salah satu solusi yang sedang diterapkan oleh Kementerian Pendidikan dan Kebudayaan adalah belajar dari rumah (home learning).

Sistem belajar dari rumah yang sudah diterapkan sejak masa pandemi covid-19, yakni terhitung Maret 2020 dipandang belum optimal. Metode yang diterapkan adalah pihak sekolah membagikan semua buku sebagai sumber belajar kepada peserta didik untuk belajar mandiri di rumah. Metode lain yang juga diterapkan adalah virtual learning. Kenyataan yang terjadi bahwa kedua metode tersebut dikeluhkan oleh orang tua peserta didik dan peserta didik itu sendiri. Orang tua merasa secara tidak langsung dituntut untuk menjadi guru bagi anaknya. Hal ini tentu saja membebani atau mengganggu tugas pokok orang tua. Selain itu, banyak orang tua yang berpendidikan rendah dan tidak mampu memahami secara utuh materi yang harus diajarkan kepada anaknya. Kendala lain yang terjadi adalah keterbatasan ekonomi orang tua untuk memfasilitasi anaknya dalam virtual learning. Dalam hal ini, orang tua tidak mampu mengadakan android handphone dan kuaota internet bagi anaknya. Kusumah (2020: 153) mengatakan bahwa peran orang tua sangat besar dalam meningkatkan kemampuan dan prestasi belajar anak. Di samping itu, virtual learning tidak dapat menjangkau pendidikan di daerah tertentu yang tidak tersedia jaringan internet (Syah dalam Syofyan, 2015: 6).

Uraian kendala di atas juga dialami oleh peserta didik di SMPN Tublopo. Sekolah ini terletak di Desa Tublopo, Kecamatan Bikomi Selatan, Kabupaten Timor Tengah Utara (TTU), Provinsi Nusa Tenggara Timur. Jarak tempuh ke sekolah \pm 16 km dari pusat Kota Kefamenanu. Guru-guru yang mengabdi di sekolah ini sebagian besar berdomisili di pusat Kota Kefamenanu sehingga jarang melakukan kunjungan ke rumah peserta didik untuk mengomptimalkan sistem belajar dari rumah pada masa pandemi covid-19. Oleh karena itu, program Rumah Belajar ini bertujuan untuk memberikan pemahaman yang komprehensif terhadap para siswa terkait materi yang diberikan dalam sistem BdR selama masa pandemi Covid-19.

Kegiatan pengabdian terkait Rumah Belajar pernah dilakukan oleh Gulo, dkk. (2021). Pengabdian Gulo, dkk. mengaplikasikan Koncokelas: sebuah Aplikasi Video Pembelajaran Berbasis Animasi sebagai Usaha Pemberdayaan Anak Putus Sekolah. Pengabdian ini bertempat di Desa Duria dengan fokus pengabdian terhadap anak-anak putus sekolah. Penerapan Koncokelas menunjukkan adanya peningkatkan pengetahuan dan keterampilan anak-anak putus sekolah. Selain itu, peningkatan juga terlihat pada minat dan motivasi belajar. Pengabdian lain terkait program rumah belajar pun dilakukan oleh Yuniarto dan Sutarno (2020). Fokus pengabdian ini adalah pengayaan mata pelajaran Bahasa Inggris pada jenjang SD dan SMP di daerah Podorejo. Kegiatan ini mengambil waktu di sore hari dengan melibatkan beberapa guru dan tiga mahasiswa. Program Rumah Belajar tersebut memberikan kontribusi yang sangat positif karena para peserta pengabdian dapat belajar Bahasa Inggris dengan mudah dan murah, serta menggunakan model dan metode yang menyenangkan.

Kedua program Rumah Belajar di atas memiliki lokasi dan sasaran pengabdian yang berbeda, namun pada dasarnya memiliki tujuan yang sama yakni, mengoptimalkan hasil belajar siswa dalam pembelajaran. Sedangkan program Rumah Belajar dalam kegiatan pengabdian ini dilaksanakan di SMPN Tublopo dengan mekanisme pelaksanaaan yang sama, yakni berupa pengayaan materi pembelajaran di waktu extra. Perbedaan pengabdian ini dengan kedua pengabdian terdahulu di atas terletak pada fokus pengayaan, yakni mata pelajaran Bahasa Indonesia dan Bahasa Inggris.

\section{Metode}

Kegiatan pengabdian ini dilakukan dengan tiga tahapan, yakni survei, permohoman izin, dan pelaksanaan pengabdian. Pada tahap survei, tim Pengabdi melakukan survei ke tempat sasaran 
untuk memastikan pelaksanaan kegiatan pengabdian kepada masayarakat dan menentukan tempat (rumah) untuk pelaksanaan kegiatan pengabdian ini. Selain itu, pada tahap ini juga tim pengabdi mendata jumlah peserta pengabdian. Pada tahap permohonan izin, tim pengabdi mengurus surat izin pengabdian di pemerintah desa setempat untuk pelaksanaan kegiatan pengabdian. Pada tahap pelaksanaan, tim pengabdi bertemu langsung dengan orang tua dan peserta pengabdian. Selanjutnya, tim pengabdi membagi peserta ke dalam beberapa rombongan belajar sesuai dengan protokol kesehatan covid-19 (setiap rombel beranggotakan $5-7$ orang). Tim pengabdi membuat jadwal pelaksanaan program rumah belajar dan melakukan pengabdi berdasarkan jadwal yang sudah dibuat. Sasaran pelaksanaan kegiatan pengabdian ini adalah siswa-siswa kelas VII SMP Negeri Tublopo Tahun Pelajaran 2020/2021 yang berdomisili di Desa Tublopo. Berdasarkan analisis situasi oleh tim pengabdi pada saat pelaksanaan kegiatan, siswa SMPN Tublopo masih sangat membutuhkan bimbingan dan pendampingan dalam bentuk program Rumah Belajar. Oleh karena itu, rencana selanjutnya berdasarkan hasil evaluasi pelaksanaan kegiatan ini adalah tim pengabdi melakukan pengembangan program Rumah Belajar untuk mengoptimalkan kapasitas siswa SMPN Tublopo dalam memahami materi pembelajaran selama pandemi Covid-19 maupun setelah pandemi. Materi Bahasa Indonesia yang diajarkan dalam kegiatan pengabdian ini adalah pantun, gurindam, syair, dan teks fabel. Sedangkan materi Bahasa Inggris yang diajarkan adalah penggunaan adjective, how to describe something, someone, and certain place, how to promote, dan How to get message of a song. Bahan-bahan yang digunakan dalam kegiatan pengabdian ini berupa masker dan handsanitizer. Sedangkan alat yang digunakan adalah Laptop, LCD, dan kamera. Pengabdian ini berupa pengayaan materi kepada siswa. Setiap materi pengayaan dikuti dengan pemberian latihan dan bimbingan dalam kelompok kecil serta pemberian post test. Hasil latihan dan post test dianalisis secara menyeluruh dan digunakan sebagai bahan evaluasi.

\section{Hasil dan Pembahasan}

Sasaran pengabdian ini adalah siswa kelas VII SMP Negeri Tublopo tahun pelajaran 2020/2021. Peserta pengabdian yang dilibatkan sebanyak 29 orang dengan rincian laki-laki 13 orang dan perempuan 16 orang yang dibagi menjadi 1 rombongan belajar (rombel).

Tim pengabdi mengawali pengabdian ini dengan memastikan pelaksanaan kegiatan yang diikuti dengan pembuatan jadwal pelaksanaan. Selanjutnya tim pengabdi mempersiapkan hal-hal administratif, alat yang diperlukan, serta keperluan protokol kesehatan Covid-19. Hal-hal administratif yang dipersiapkan dalam awal kegiatan pengabdian ini berupa surat izin pengabdian dari LPPM Unimor, daftar hadir, jadwal pelaksanaan pengabdian, dan pembuatan materi pengabdian. Alat-alat yang diperlukan dalam pelaksanaan pengabdian ini berupa buku tulis, ballpoint, spidol, penghapus, laptop, LCD, dan kamera. Keperluan protokol kesehatan yang diperlukan berupa handsanitizer dan masker.

Dasar pelaksanaan kegiatan pengabdian ini adalah pengayaan materi yang sudah dipelajari oleh siswa saat sistem Belajar dari Rumah (BdR) akibat pandemi Covid-19 pada semester genap tahun pelajaran 2020/2021. Kegiatan BdR yang diterapkan di SMP Negeri Tublopo terhitung Januari 2021 hingga Mei 2021. Oleh karena itu, materi yang diajarkan sesuai dengan distribusi materi pada silabus kurikulum 2013 terhitung pertemuan pertama di awal semester hingga pertemuan terakhir pada bulan Mei 2021.

Ada dua mata pelajaran yang diajarkan dalam kegiatan pengabdian berbasis pengayaan, yakni Mata Pelajaran Bahasa Indonesia dan Bahasa Inggris. Mata Pelajaran Bahasa Indonesia diampuh oleh Joni Soleman Nalenan, S.Pd., M.Hum., sedangkan Bahasa Inggris diampuh oleh Yanuarius Seran, S.Pd., M.Sc. Dalam pelaksanaan pengabdian ini, tim pengabdian dibantu oleh 2 orang mahasiswa sebagai pembantu lapangan. 
Tim pengabdi melaksanakan kegiatan pengabdian sesuai jadwal yang sudah dibuat dan disepakati oleh kepala sekolah. Kegiatan pengabdian ini dilaksanakan selama 12 kali pertemuan dengan rincian dua kali pertemuan tiap minggu. Pelaksanaan pertemuan pertama dilaksanakan pada 5 April 2021 hingga berakhir pada 7 Juni 2021. Jadwal pelaksanaan kegiatan pengabdian terlampir.

Teknis pelaksanaan kegiatan pengabdian di kelas adalah kedua tim pengabdi bersama-sama hadir di kelas. Strategi pelaksanaannya diatur dengan sistem pergantian peran. Dalam hal, kedua tim pengabdian selalu bertukar peran, yakni sebagai pengajar dan fasilitator pada setiap pertemuan. Dengan sistem pergantian peran ini, tim pengajar mengarjakan dua mata pelajaran sekaligus dalam setiap pertemuan. Setiap mata pelajaran dilaksanakan selama 60 menit (1 jam). Pembantu lapangan bertugas membantu tim pengabdian dalam hal mempersiapkan perlengkapan yang dibutuhkan pada saat pelaksanaan pengayaan.

Pengabdian mengawali setiap pertemuan pengayaan di kelas dengan pembagian masker dan penyemprotan handsanitizer kepada semua siswa. Sebelum pengayaan materi, didahului dengan doa yang dipimpin oleh tim pengabdi maupun siswa. Selanjutnya, tim pengabdi memberikan materi sambil mengedarkan daftar hadir kepada peserta. Tim pengabdi yang bertugas sebagai pengajar, mengajarkan materi sesuai dengan topik yang sudah disiapkan, sedangkan pengabdi yang bertugas sebagai fasilitator memfasilitasi peserta saat kegiatan pengayaan dilaksanakan oleh pengajar. Pada setiap pertemuan, pengajar menyajikan materi sesuai topik \pm 20 menit. Selanjutnya, memberikan pertanyaan kepada peserta untuk bertanya jika ada materi yang belum dipahami. Pengajar menjawab dan menjelaskan pertanyaan peserta jika ada. Selanjutnya pengajar memberikan latihan-latihan kepada peserta baik secara individu maupun dalam bentuk kelompok. Proses pelaksanaan pengayaan di kelas tidak jauh berbeda dengan proses pembelajaran riil yang diterapkan oleh guru-guru di kelas.

Kegiatan pengabdian ini dilaksanakan selama dua belas kali pertemuan pengayaan yang semula bertempat di sekolah. Namun, terkendala dengan penyebaran pandemi Covid-19, maka tim pengabdi membagi peserta pengabdian ke dalam empat lokasi pelaksanaan. Lokasi pertama bertempat di sekolah, yakni SMPN Tublopo. Lokasi kedua, ketiga, dan keempat bertempat di rumah warga.

\section{Kesimpulan}

Hasil analisis pekerjaan siswa melalui pengayaan ini menunjukkan adanya peningkatan pemahaman siswa terhadap mata pelajaran Bahasa Indonesia dan Bahasa Inggris cukup siginifikan. Dengan demikian, program Rumah Belajar berhasil diterapkan dalam mengatasi masalah virtual learning di masa pandemi Covid-19. Berdasarkan hasil pelaksanaan kegiatan pengabdian ini, bimbingan dan pendampingan dalam bentuk program Rumah Belajar masih sangat dibutuhkan para siswa di SMPN Tublopo. Oleh karena itu, perlu adanya pengembangan program Rumah Belajar untuk mengoptimalkan kapasitas siswa SMPN Tublopo dalam memahami materi pembelajaran selama pandemi Covid-19 maupun setelah pandemi. Tim pengabdi pun telah melakukan kesepakatan dengan pihak sekolah untuk melakukan MoU agar kegiatan ini tetap berkelanjutan.

\section{Daftar Pustaka}

Arifa, Nurul. (2020). Tantangan Pelaksanaan Kebijakan Belajar dari Rumah dalam Masa Darurat Covid-19. Jurnal Info Singkat, Volume 12, Nomor 7, Halaman $13-18$.

Cahyati, N., \& Kusumah, R. (2020). Peran orang tua dalam menerapkan pembelajaran di rumah saat pandemi Covid 19. Jurnal golden age, 4(01), 152-159.

Gulo, Y. T. M., Nasution, A. K., Batubara, B. M., \& Waruwu, S. (2021). Koncokelas: Aplikasi Video Pembelajaran Berbasis Animasi sebagai Usaha Pemberdayaan Anak Putus Sekolah melalui 
BERNAS:

Jurnal Pengabdian Kepada Masyarakat

Rumah Belajar. Pelita Masyarakat, 2(2), 83-94.

Yuniarti, F., \& Sutarno, S. (2020). Mengadakan Program Rumah Belajar Bimbingan Belajar Bahasa Inggris "English Is Not Expensive" Di Desa Podorejo Sebagai Cara Untuk Meningkatkan Kemampuan Anak-Anak Dan Remaja Dalam Memahami Bahasa Inggris. Bagimu Negeri: Jurnal Pengabdian Kepada Masyarakat, 4(1), 22-26.

Zulfia, R., \& Syofyan, E. (2015). Pengaruh Fasilitas Belajar di Rumah, Minat Belajar dan Motivasi Belajar terhadap Hasil Belajar Komputer Akuntansi. Jurnal Kajian Pendidikan Ekonomi, 2(110). 